Jurnal Bimbingan dan Konseling Ar-Rahman
Volume 7, Nomor 1, Tahun 2021
Tersedia Online: http://ojs.uniska.ac.id/index.php/BKA
e-ISSN 2477-6300

\title{
STUDI FENOMENOLOGI MOTIVASI KEBUTUHAN PENGGUNAAN TIK- TOK DALAM PERKEMBANGAN KEMATANGAN SOSIAL SISWA SEKOLAH DASAR
}

\author{
Miranti Widi Andriani \\ STKIP PGRI Bangkalan \\ mirantiwidi@stkippgri-bkl.ac.id
}

\begin{abstract}
ABSTRAK
Maraknya penggunaan apikasi Tik-Tok para siswa sekolah dasar tak luput dari peranan motivasi yang menggerakkan perilaku untuk mencapai tujuan tertentu. Perkembangan sosial anak sekolah dasar dalam menunjukkan kemampuan menempatkan diri sebagai individu dalam kelompok bermain, memahami lingkungan sosial yang berpusat pada teman sebaya. Tujuan penelitian untuk menggambarkan pandangan, sikap dan perilaku penggunaan aplikasi Tik-Tok yang berdasar pada motivasi kebutuhan Maslow dalam perkembangan kematangan sosial. Penelitian ini menggunakan rancangan kualitatif pendekatan fenomenologi. Hasil temuan: 1) perilaku dalam pemenuhan kebutuhan fisiologis menggambarkan kemampuan anak dalam menganalisis situasi belum menunjukkan kematangan sosial, 2) kekhawatiran anak terhadap larangan penggunaan gawai menunjukkan belum terpenuhinya kebutuhan rasa aman sehingga membuat tingkat kematangan emosi anak menjadi rendah dan berpengaruh pada kematangan sosial, 3) Mempererat persahabatan sebagai tujuan bermain Tik-Tok adalah cara anak memenuhi kebutuhan kasih sayang dengan teman. Anak yang diterima kelompok, kematangan sosialnya akan baik, 4) kematangan sosial dapat dipengaruhi oleh pemenuhan kebutuhan diri untuk dihargai. Sehingga memunculkan perilaku keamampuan agar diterima kelompok, 5) berperilaku konsisten dan bersungguhsungguh dalam menunjukkan kemampuan diri, hal ini akan berkaitan dengan keinginan dihargai dan diakui kemampuan dirinya sebagai wujud aktualisasi diri. Simpulan dari penelitian ini adalah motivasi kebutuhan dalam penggunaan aplikasi Tik-Tok dapat menjadi sumber dorongan perilaku dan kematangan sosial.
\end{abstract}

Kata Kunci: Motivasi Kebutuhan; Tik-Tok; Kematangan Sosial

\begin{abstract}
The widespread use of Tik-Tok application for elementary school students cannot be separated from the role of motivation that drives behavior to achieve certain goals. The social development of elementary school children in the Competency Standards for the Independence of Learners is at maturity relationships with peers (social environment). The research objective is to describe the views, attitudes and behavior of using the Tik-Tok application based on Maslow's motivational needs in the development of social maturity. This study used a qualitative design with a phenomenological approach. The findings: 1) the fulfillment of physiological needs behavior describes the ability to analyze situations that indicate social maturity, 2) refers to the prohibition on the use of devices that indicates the fulfillment of the need for security so that the emotional maturity level of the child becomes low and affects social maturity, 3) Strengthens friendship as the goal of playing Tik-Tok is a way for children to meet their needs for affection with friends. Children who are accepted by the group will have good social maturity, 4) social maturity can be realized by self-fulfillment. So that the ability to be accepted, 5) behave consistently and seriously in showing self-ability, this will be related to his desire and ability as a form of selfactualization. The conclusion from this research is the motivation needs in using the Tik-Tok application can be a source of behavior and social maturity.
\end{abstract}

Keywords: Motivation Of Need; Tik-Tok; Social Maturity

Dipublikasikan Oleh :

UPT Publikasi dan Pengelolaan Jurnal 


\section{PENDAHULUAN}

Bermula sebagai alat komunikasi, gawai atau telepon pintar (smart phone) telah berevolusi menjadi kebutuhan dan gaya hidup masyarakat modern. Gawai selalu muncul dengan aplikasiaplikasi yang mengikuti perkembangan zaman. Aplikasi tersebut mengarah ke berbagai kebutuhan. Cakupan akomodasi mulai dari kebutuhan bersifat primer hingga hiburan. Gawai hampir dimiliki oleh semua orang mulai dari anak-anak, remaja sampai dewasa. Hal tersebut juga diungkapkan oleh Novitasari \& Khotimah (2016) yang menyatakan bahwa di era globalisasi, masyarakat telah memiliki gawai dari berbagai kalangan baik anakanak, remaja, dewasa dan sampai lanjut usia. Di jenjang sekolah dasar, penggunaan telepon pintar dipakai sebagai alat belajar khususnya saat pandemi seperti sekarang menjadi sarana wajib dimiliki. Tentu ada dampak positif dan dampak negatif yang menyertai penggunaan gawai yang masih membutuhkan peran orang tua dalam mengawasi anak.

Gawai dengan segala aplikasi yang kekinian mulai dari media sosial dan permainan menjadi salah satu daya tarik yang sangat luar biasa bagi pelajar sekolah dasar. Salah satu aplikasi yang sedang hangat dibicarakan adalah aplikasi Tik-Tok. Aplikasi ini merupakan wadah dalam menyampaikan pesan mengguna dengan membuat video musik pendek mereka sendiri. Hal ini juga diulas oleh Anindita (2020) aplikasi TikTok mengalami kenaikan pesat dalam hal peminat di akhir tahun 2019 dengan kepopulerannya dalam memberikan tempat berkreasi dan memiliki gaya mereka sendiri ketika membuat video.

Motivasi menjadi sumber kekuatan yang membangkitkan rasa ingin tahu untuk mencoba aplikasi Tik-Tok para siswa sekolah dasar. Perilaku tampak yang ditunjukkan dengan menggunakan aplikasi Tik-Tok mulai mengunduh aplikasi, melakukan pencarian video yang menarik, hingga mencoba membuat konten pada aplikasi Tik-Tok. Motivasi menggerakkan perilaku untuk mencapai tujuan-tujuan yang tersirat dalam penggunaan aplikasi atau dapat dimaknai sebagai motivasi kebutuhan. Senada dengan hal tersebut Mendari (2010) menjelaskan bahwa motivasi merupakan suatu kekuatan yang mendorong seseorang untuk melakukan suatu kegiatan sedangkan motif yang bersifat potensial dan aktualisasinya dinamakan motivasi.

Maslow membawa konsep dan teori tingkatan kebutuhan dan membaginya dalam lima tingkatan. Dimulai dari kebutuhan dasar yang harus terpenuhi (fisiologis), kebutuhan akan rasa aman menjadi kebutuhan kedua yang akan menjadi fokus pemenuhan. Jika tingkatan kedua sudah terpenuhi, maka kebutuhan cinta dan kasih saying akan menjadi tingkatan ketiga yang berusaha dipenuhi. Kebutuhan penghargaan baik dari individu maupun kelompok menjadi kebutuhan keempat dan terakhit adalah kebutuhan aktualisasi atau bisa disebut pernyataan diri. Umumnya digambarkan dengan bentuk piramida. Tersusun dari tingakat pertama adata dasar berada di bagian bawah dan seterusnya. Mendari (2010) mengutip penyataan Maslow yang mengemukakan bahwa individu berperilaku dalam upaya untuk memenuhi kebutuhan yang bersifat hierarkis yang ditulis bukunya Motivation and Personality Maslow memperkenalkan Hierarchy of Needs.

Ulasan mendalam perlu dilakukan mengingat aplikasi Tik-Tok sangat digandrungi oleh pelajar tidak terkecuali siswa sekolah dasar. Siswa sekolah dasar dengan kisaran usia 10-12 tahun berada pada masa kanak-kanak akhir. Masa ini ditandai dengan beberapa perkembangan. Penjelasan lebih rinci juga dipaparkan Santrock (2013) bahwa perkembangan masa kanak-kanak akhir diantaranya meliputi perkembangan fisik, perkembangan kecerdasan, perkembangan bahasa, perkembangan sosial dan perkembangan emosi. Semua perkembangan tersebut tentunya harus diperhatikan orang tua saat mendampingi anak dalam menggunakan aplikasi Tik-Tok.

Perkembangan sosial anak sekolah dasar didominasi hubungan dengan kelompok bermain dan membutuhkan kemandirian agar berada pada kematangan hubungan dengan teman sebaya. Senada dengan penelitian terdahulu menemukan bahwa pola permainan dengan teman sebaya efektif dalam meningkatkan keterampilan sosioemosional baik secara individu maupun kelompok (Andriani, 2018). Guru dan orang tua harus membimbing anak agar mampu dan mandiri berada pada tataran menjalin persahabatan dengan teman sebaya dan menjunjung tinggi norma bersama. Kematangan sosial ini diharapkan dapat membantu siswa secara luwes berada di tengahtengah lingkungan sosial dengan teman sebaya secara kohesif. Hal ini dapat diamati dari perilaku tampak yang didasari oleh motif-motif pemenuhan kebutuhan diri.

Paparan data awal hasil dari observasi menunjukkan aktifitas siswa sekolah dasar yang kerap berkumpul dan membuka aplikasi Tik-Tok dan menggerakkan tubuhnya sesuai irama Tik-Tok. Perilaku tampak ini merupakan hasil dari motivasi kebutuhan. Beberapa penelitian terdahulu telah mencoba mengulas penelitian tentang aplikasi Tiktok dan menghasilkan beberapa hal seperti penelitian Aprilian et al. (2020) menemukan 
Miranti Widi Andriani

Jurnal Bimbingan dan Konseling Ar-Rahman

Volume 7, Nomor 1, Tahun 2021

e-ISSN 2477-6300

adanya indikasi hubungan sebab (penggunaan aplikasi Tik-Tok) dengan akibat (perilaku narsisme), penggunaan aplikasi Tik-Tok yang intens berdampak pada tinggina perilaku narsisme. Penelitian senada tentang Tik-Tok yang dilakukan oleh Chusna et al. (2020) menghasilkan kesimpulan genre music DJ remix biasa disajikan pada club malam dan dijadikan lagu pengiring TikTok mempengaruhi sikap serta tingkah laku dan memicu penyimpangan sosial anak sekolah dasar.

Paparan diatas mengerucutkan tujuan penelitian ini berupaya mengungkap mengenai pandangan, sikap dan perilaku subjek dalam penggunaan aplikasi Tik-Tok yang merujuk pada motivasi kebutuhan Maslow. Diharapkan hasil penelitian dapat menggambarkan setiap tingkatan motivasi kebutuhan dan perilaku tampak yang mengiringi. Motivasi kebutuhan Maslow dipilih sebagai dasar motivasi terbentuknya perilaku kematangan sosial.

\section{METODE}

Penelitian ini menggunakan rancangan kualitatif dengan pendekatan fenomenologi, Dalam penelitian ini, untuk memperoleh data yang disesuaikan dengan fokus penelitian. Teknik Snowball Sampling (bola salju) dipilih untuk dapat menggali secara mendalam. Pengambilan data pada subjek pertama dilakukan hingga menemui data jenuh, subjek kedua dan seterusnya dapat dilakukan pengambilan data jika data dirasa masih belum dapat menjawab rumusan penelitian. Jumlah subjek yang menjadi sumber data sebanyak empat siswa. Deskripsi singkat dari masing-masing subjek adalah sebagai berikut:

1. Subjek 1. Subjek penelitian pertama berinisial AU. Berjenis kelamin perempuan, berusia 11 tahun. AU merupakan anak pertama dari empat bersaudara dan sedang duduk dibangku kelas 5 SD. Ayah AU adalah seorang teknisi, sedangkan ibu AU adalah ibu rumah tangga.

2. Subjek 2. Subjek kedua berinisial UL. Berjenis kelamin perempuan, berusia 12 tahun. UL merupakan anak kedua dari tiga bersaudara. Ayah UL merupakan ASN dan ibu wiraswasta.

3. Subjek 3. Subjek ketiga berinisial FT merupakan anak kedua dari dua bersaudara. Berjenis kelamin perempuan, berusia 10 tahun dan duduk di bangku kelas 4 SD. Ayahnya adalah seorang teknisi kapal laut dan ibunya adalah ibu rumah tangga.

4. Subjek 4. Subjek keempat berjenis kelamin perempuan dengan inisial RK. Duduk di bangku kelas $5 \mathrm{SD}$ dan berusia 11 tahun.
Merupakan anak pertama dari dua bersaudara.

Ayah dan ibunya merupakan ASN.

Peneliti menggambarkan dengan memahami pemaknaan diri subjek yaitu siswa sekolah dasar terhadap penggunaan aplikasi Tik-Tok. Pemaknaan diri berfokus pada dasar perilaku, pendapat, pandangan, argumen, keyakinan dan penjelasan mengenai gambaran abstrak motivasi kebutuhan penggunaan aplikasi Tik-Tok. Kemudian peneliti menarik pemaknaan motivasi kebutuhan dalam kematangan sosial. Sehingga data menjadi lengkap. Data penelitian berupa tindakan dan katakata yang diucapkan oleh subjek peneliti serta fenomena-fenomena yang ada di lapangan yang terkait dengan fokus penelitian.

Wawancara mendalam sebagai upaya mendapatkan deskripsi yang utuh ditambah pengamatan pada perilaku tampak digunakan sebagai cara untuk pengumpulan data. Tingkat partisipasi atau keterlibatan dimaksud terentang dari partisipasi penuh (complete) - aktif (active) menengah (moderate) - pasif (passive) sampai non partisipatif. Pada penelitian ini peneliti berada pada posisi aktif. Maka, untuk melengkapi data, penambahan bahan kajian pustaka baik melalui literasi maupun internet. Dengan melakukan pengecekan keabsahan data, triangulasi membantu peneliti dapat melakukan penarikan makna dan analisis deskripsi.

\section{HASIL DAN PEMBAHASAN}

Data-data yang berhasil digali dari subjek antara lain dari pernyataan yang diperoleh dari hasil wawancara kepada subjek yang mendukung analisis.

a. Motivasi Kebutuhan Penggunaan Aplikasi Tik-Tok Oleh Siswa Sekolah Dasar Dari Segi Kebutuhan Fisiologis

Pertanyaan yang dilontarkan peneliti adalah bagaimana subjek membagi waktu antara tidur dan main tik-tok. Berikut ini kutipan hasil wawancara yang menggambarkan motivasi kebutuhan fisiologis.

"Aku tu mbak, kalau sudah main tik-tok kadang suka lupa untuk tidur siang soalnya kalau main tik-tok itu bisa buat senang" (AU/11th/10 Nov 2020).

"Sebelum tidur biasanya aku sempetin lihat tik-tok, ya lihat aja apa ada yang viral. Kalau biasanya masuk kamar jam 9 malem paling nanti baru beneran tidur ya 
jam 10 malam lah mbak" (UL/12th/12

Nov 2020).

Kutipan diatas menggambarkan bahwa subjek lebih memilih mengesampingkan kebutuhan fisiologis yaitu tidur dengan memilih tidak tidur siang dan tidur lebih larut.

Peneliti melengkapi pertanyaan untuk menangkap gambaran diri subjek dengan mengajukan pertanyaan apakah subjek merasakan pengaruh rasa lapar pada keinginan bermain tik-tok.

"Kalau lagi laper, tapi ada temen-temen ngajakin main jadi ilang lapernya hahahaha" (FT/10th/25 Nov 2020).

"Uang jajan dari mama aku beliin paketan soalnya kalau tidak punya paketan rasanya bingung dan bosen mau ngapain. Makan kadang sampai lama soalnya sambil lihat HP" (RK/11th/12 Nov 2020).

\begin{tabular}{lrr}
\multicolumn{2}{c}{ Kutipan diatas } & menggambarkan bahwa \\
subjek kembali & lebih & memilih \\
mengesampingkan & kebutuhan fisiologis
\end{tabular}
makan.

b. Motivasi Kebutuhan Penggunaan Aplikasi Tik-Tok Oleh Siswa Sekolah Dasar Dari Segi Kebutuhan Rasa Aman

Berikut ini kutipan hasil wawancara yang menggambarkan motivasi kebutuhan rasa aman.

"Aku main tik-tok kalau tidak ada kerjaan dan ndak ada tugas sekolah, baru deh aku lihat aplikasi dan main tik-tok. Tapi kalau ada mama, aku berhenti main tik-toknya, jadi mama ndak pernah tahu aku main tiktok apa ndak" (UL/12th/12 Nov 2020).

"Aku main tik-tok ndak ada tekanan kok mbak, ndak ada yang maksain. Ya aku pingin aja karena lihat temen-temen pada main tik-tok. Bahkan kalau mama tahu ya ndak apa-apa kan cuma main tik-tok . walaupun kadang suka kesel sih diomelin kalo terus-terusan pegang HP' (RK/11th/12 Nov 2020).

“Aku pernah ndak boleh pegang HP sama ayah karena sering lihat tik-tok, jadi aku kalau ada ayah sembunyi-sembunyi mainnya. Tapi kalau mam biasa aja sih mbak" (AU/11th/10 Nov 2020).
Kutipan diatas menggambarkan bahwa subjek akan merasa was-was saat mendapat teguran dari orang tua karena sering bermain Tik-Tok. Kekhawatiran fasilitas gawai disita orang tua memunculkan perilaku hanya bermain Tik-Tok di dalam kamar, bermain TikTok saat bersama teman dan di luar rumah. Dari temuan tersebut dapat dimaknai anak merasa kurang aman.

c. Motivasi Kebutuhan Penggunaan Aplikasi Tik-Tok Oleh Siswa Sekolah Dasar Dari Segi Kebutuhan Dicintai dan Kasih Sayang

Berikut ini kutipan hasil wawancara yang menggambarkan motivasi kebutuhan dicintai dan kasih sayang.

"Kalau main tik-tok itu bisa buat seneng, apalagi main tik-toknya bareng tementemen, sеruиuи banget itu bisa heboh. Aku gak pernah bikin sendiri selalu bareng dengan teman-teman" (AU/11th/10 Nov 2020).

"Main tik-tok itu bisa bikin erat persahabatan, karena main tik-tok bareng itu, temen-temen bisa main ke rumah seperti Puput, Adel, Iim sama tementemen yang lain juga" (FT/10th/25 Nov 2020).

"Kalau main tik-tok, ya aku ikut tementemen maunya main apa ya aku ikut aja. Misal mereka maunya 'bang jago' ya aku ikut aja" (UL/12th/12 Nov 2020).

"Sering banget janjian misalnya setelah asyar untuk kumpul bikin konten. Biasanya setelah pulang sholat asyar kan sholat biasanya di masjad bareng, nah setelah itu biasanya kita kumpul" (RK/11th/12 Nov 2020).

Kutipan diatas menggambarkan bahwa subjek memenuhi kebutuhan dicintai dan kasih sayang dengan menggunakan aplikasi Tik-Tok adalah agar dapat mempererat persahabatan.

d. Motivasi Kebutuhan Penggunaan Aplikasi Tik-Tok Oleh Siswa Sekolah Dasar Dari Segi Kebutuhan Penghargaan

Berikut ini kutipan hasil wawancara yang menggambarkan motivasi kebutuhan penghargaan. 
Miranti Widi Andriani

Jurnal Bimbingan dan Konseling Ar-Rahman

Volume 7, Nomor 1, Tahun 2021

e-ISSN 2477-6300

"Main tik-tok buat seru-seruan aja mbak. Nggak gimana-gimana. Biar seru aja gitu kalau kumpul temen-teman. Lagian main tik-tok juga Cuma buat refreshing mbak, banyak tugas daring jadi capek. Jadi kalau udah main tik-tok rasanya seneng aja, kompak gitu" (RK/11th/12 Nov 2020).

"Aku main tik-tok dikamar mbak, kadang malu kalau dilihat orang. Kalau sama temen-temen masih PD (Percaya Diri) walaupun di luar kamar, pokonya ada temennya ya mbak. Ada rasa takut diejek sih kalau tidak bisa main tik-tok atau joget, takut dibilang tidak gaul gitu" (RK/11th/12 Nov 2020).

"Kadang aku tu mikirnya main tik-tok biar semua temenku tau gitu kalau aku bagus jogetnya, atau bisa ngikutin gerakan dengan bagus gitu. Aku jadi seneng kalau temenku memuji videoku" (AU/11th/10 Nov 2020).

Kutipan diatas menggambarkan bahwa subjek merasa enggan dicemooh sebagai anak yang tidak gaul atau tidak up date. Hal ini dapat dimaknai, anak berusaha mengembangkan diri agar diakui dan dihargai oleh teman bermain.

e. Motivasi Kebutuhan Penggunaan Aplikasi Tik-Tok Oleh Siswa Sekolah Dasar Dari Segi Kebutuhan Aktualisasi Diri

Berikut ini kutipan hasil wawancara yang menggambarkan motivasi kebutuhan aktualisasi diri.

"Sekarang kan lagi musim main tik-tok 'bang jago', itu ya mbak, aku sukaaaaaa banget. Aku juga udah buat tu tik-tok 'bang jago'. Biasanya kalau aku main tiktok, adekku suka niru juga, kadang dia juga minta divideoin juga. Aku tu kalau bikin tik-tok harus buat yang menarik dan gerakannya yang heboh. Kaya gini lho mbak, misalnya 'bang jago' ya harus semangat (Subjek memperagakan gerakan dance tik-tok dengan luwes dan bersemangat, sembari menyanyikan lirik lagu 'bang jago' dengan fasih sambil menyanyikan lirik)" (UL/12th/12 Nov 2020).

“Aku tu sering ngedit berjam-jam biar hasilnya bagus, kan seneng kalau hasilnya bagus rasanya puas gitu mbak" (AU/11th/10 Nov 2020).

"Kalau mengulang gerakan berkali-kali sama teman-teman ya sering banget mbak. Kadang bisa sampai lebih dari lima kali ulang. Sampai capek banget tapi seru sih. Kan senang juga kakau hasilnya sempurna" (FT/10th/25 Nov 2020).

Kutipan diatas menggambarkan bahwa subjek merasa senang mengeksplorasi aplikasi Tik-Tok, kegiatan itu dilakukan untuk membuat konten yang menarik dan bagus hasil editannya. Hal ini berarti subjek menunjukkan kemampuan yang dimiliki.

Maslow membagi tingkatan hirarki kebutuhan menjadi lima, pada tingkatan dasar terdapat kebutuhan yang bersifat fisiologis, tingkatan kedua kebutuhan rasa aman, tingkatan ketiga pemenuhan kebutuhan rasa kasih dan sayang, kemudian ditingkatan keempat ada kebutuhan tentang penghargaan dan kebutuhanuntuk menyatakan diri atau sering disebut aktualisasi ditingkatan kelima. A.H. Maslow (1943) memaparkan bahwa tingkat kepuasan kebutuhan bersifat relatif. Hal ini dapat dimaknai bahwa, setiap individu memiliki kekhasan, hal itu akan seiring dengan keunikan kurva pemenuhan motivasi kebutuhan. Setiap tingkatan kebutuhan berpotensi memicu motivasi individu yang akhirnya menjadi dasar perilaku.

Berikut gambaran inti penelitian motivasi kebutuhan dalam kematangan sosial. 


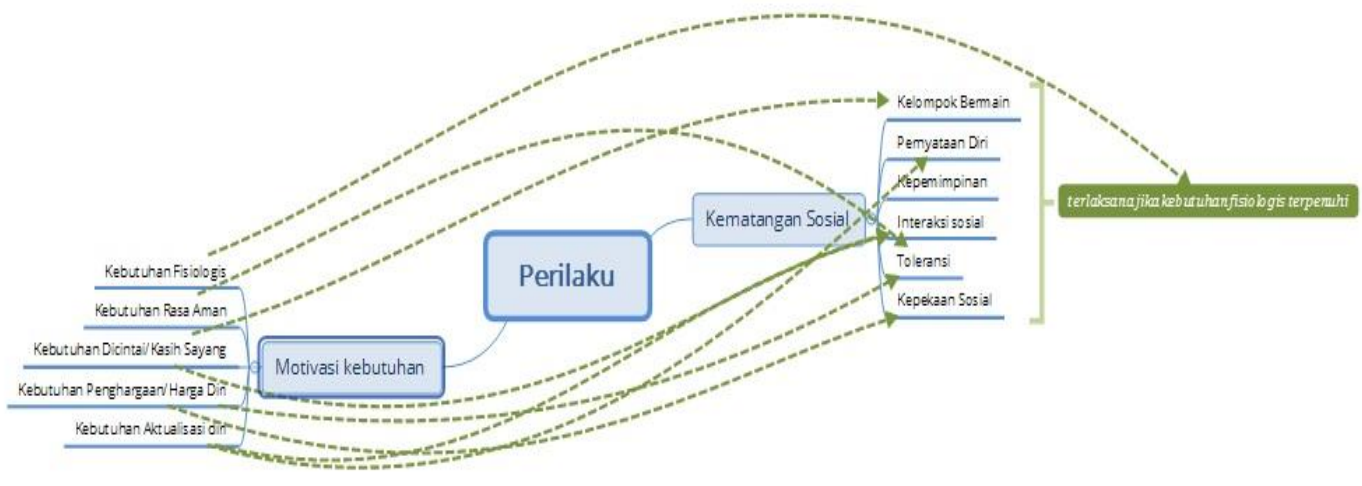

Gambar 1. Peta Konsep Analisis Penelitian

\section{Kebutuhan Yang Bersifat Fisiologis}

Hasil penelitian menunjukkan anak lebih memilih bermain Tik-Tok dan menunda makan. Perilaku muncul pada saat teman mengajak bermain Tik-Tok di jam makan. Dapat dimaknai, kebutuhan makan sebagai kebutuhan fisiologis dikesampingkan demi bermain bersama teman. Hal ini memunculkan perilaku seperti menunda jam makan, makan dengan berlama-lama sambil melihat aplikasi Tik-Tok, kehilangan selera makan dan memilih bermain Tik-Tok dengan teman, dan merelakan uang saku untuk membeli paket data daripada membeli makanan. Hasil penelitian juga menunjukkan kebutuhan tidur sebagai kebutuhan fisiologis juga diabaikan, anak lebih memilih tidak istirahat/tidur siang dan tidur lebih larut untuk menyempatkan melihat konten diaplikasi Tik-Tok.

Berdasar temuan tersebut, dapat ditarik makna motivasi kebutuhan pada tingkatan kebutuhan fisiologis menghasilkan beberapa perilaku yang kurang baik. Senada dengan itu Trilia (2018) juga menemukan pemenuhan kebutuhan fisiologis masuk pada kategori tidak baik pada prosentase enam puluh tiga persen. Namun, kurang baiknya pemenuhan kebutuhan tidak benar-benar berarti anak mengabaikan penuh kebutuhan fisiologis seperti makan dan tidur. Walaupun terlambat dan sedikit abai, kebutuhan makan dan tidur tetap menjadi kebutuhan pokok dalam tumbuh kembang anak. Tentu hal ini masih relevan dengan pandangan Maslow yang ditulis oleh Susanto \& Lestari (2018) yaitu kebutuhan dasar merupakan kebutuhan prioritas yang harus terpenuhi. Apabila kebutuhan dasar belum terpenuhi, maka kebutuhan yang lebih kompleks tidaklah penting. Jika dikaitkan dengan masa perkembangan kanak-kanak akhir, maka kebutuhan fisiologis sangat dibutuhkan dalam perkembangan fisik anak. Peranan gizi sangat penting untuk menunjang pertumbuhan tulang dan aktifitas gerak. Aktifitas gerak yang dilakukan dalam penggunaan aplikasi Tik-Tok secara koheren sangat diperlukan untuk melatih koordinasi, keseimbangan dan penyaluran energi.

\section{Kebutuhan Rasa Aman}

Hasil penelitian menunjukkan anak akan merasa was-was saat mendapat teguran dari orang tua karena sering bermain Tik-Tok. Kekhawatiran fasilitas gawai disita orang tua memunculkan perilaku hanya bermain Tik-Tok di dalam kamar, bermain Tik-Tok saat bersama teman dan di luar rumah. Dari temuan tersebut dapat dimaknai anak merasa kurang aman. Pemberian hukuman atas perilaku yang dianggap negatif oleh orang tua membuat siswa memilih bersikap tidak terbuka. Diperlukan komunikasi yang menyenangkan antara orang tua dan anak untuk membicarakan batasan-batasan penggunaan gawai baik dari segi konten dan waktu. Mengajak anak berkomunikasi merupakan langkah preventif yang dapat dilakukan agar anak merasa aman dan meningkatkan pemahaman diri sehingga dapat mengurangi perilaku maladaptif. Aeni (2011) mengatakan bila seorang anak tidak mampu menyesuaikan diri dengan segala tuntutan, anak berpotensi melakukan perilaku maladaptif, salah satunya perilaku agresi umumnya terwujud dalam pelanggaran.

Sikap keluarga dalam memenuhi kebutuhan rasa aman dapat dilakukan dengan hal-hal seperti penerimaan yang tulus, cinta tanpa syarat dan pemberian pujian atas perilaku adaptif. Kesediaan orang tua dalam mengevaluasi pola asuh dapat membantu siswa berkembang lebih optimal. Kekhawatiran anak orang tua akan menyita gawai merupakan wujud dari buruknya komunikasi. Hal ini membuat tingkat kematangan emosi anak 
menjadi rendah. Kematangan emosi ini akan mempengaruhi kematangan sosial anak. Dimana pengelolaan perasaan (emosi) yang ada pada diri anak akan dibawa pada lingkungan sosialnya. Anak akan mengalami kesulitan beradaptasi dan mengekspresikan diri sehingga berakibat gagalnya hubungan sosial. Orang tua perlu memiliki langkah penanganan kesalahan anak yang tidak berlebihlebihan dan dengan tepat mengarahkan anak dengan mengevaluasi perilakunya.

\section{Kebutuhan Dicintai dan Kasih Sayang}

Pada tingkatan ini, temuan penelitian berupa menunjukkan anak memenuhi kebutuhan dicintai dan kasih sayang dengan menggunakan aplikasi Tik-Tok adalah agar dapat mempererat persahabatan. Tingkah laku tampak seperti mengikuti ajakan teman membuat konten, berkumpul bersama teman untuk bermain bersama, dan membuat janji temu untuk bermain Tik-Tok bersama. Mulai membentuk kelompok bermain yang dirasa memiliki kesamaan seperti kegemaran dan pandangan. Perilaku tampak tersebut dapat dimaknai kebutuhan mendapat hubungan persahabatan teman sangat mempengaruhi pola perilaku. Hal ini dapat dipahami mengingat siswa yang masuk masa kanak-kanak akhir memiliki ciri khas berusaha menyesuaikan diri dengan lingkungan teman sebaya. Budikuncoroningsih (2017) menuliskan pergaulan diantara teman sebaya dapat mempengaruhi perilaku baik pengaruh positif dan pengaruh negatif.

\section{Kebutuhan Penghargaan/ Harga Diri}

Temuan penelitian pada bagian motivasi kebutuhan harga diri adalah anak merasa enggan dicemooh sebagai anak yang tidak gaul atau tidak up date. Selain itu kebutuhan penggunaan aplikasi Tik-Tok juga diperuntukkan sebagai sarana refreshing dan menjaga kekompakan kelompok bermain. Hal ini dapat dimaknai, anak berusaha mengembangkan diri agar diakui dan dihargai oleh teman bermain. Dimensi harga diri meliputi perasaan mampu (competence), perasaan diterima secara sosial (social acceptance), perasaan mampu mengontrol diri (feeling of moral self worth) (Nora, 2015). Maka dapat dimaknai, motivasi kebutuhan ingin diterima secara sosial sebagai dasar perilaku mengikuti ajakan teman dalam membuat dan memainkan aplikasi Tik-Tok.

\section{Kebutuhan Aktualisasi Diri}

Temuan penelitian, menunjukkan anak senang mengeksplorasi aplikasi Tik-Tok, kegiatan itu dilakukan untuk membuat konten yang menarik dan bagus hasil editannya. Anak mampu melakukan proses mengedit berjam-jam untuk mendapat hasil yang maksimal. Senada dengan temuan penelitian Bujuri (2018) menemukan kebutuhan anak usia dasar dalam kebutuhan aktualiasi diri akan menunjukkan kemampuan (ability) atau bakat (talent) yang dimiliki. Dari segi motivasi kebutuhan anak berperilaku konsisten dan bersungguh-sungguh dalam menunjukkan kemampuan diri, hal ini akan berkaitan dengan kebutuhan pemenuhan harga diri dan ingin dihargai dengan kemampuan yang dimiliki sebagai wujud aktualisasi diri. Sedangkan dari sudut pandang kematangan sosial. Terdapat bebeberapa motivasi kebutuhan yang saling tumpang tindih dan menjadi dasar perilaku sosial. Beberapa motivasi kebutuhan itu antara lain kebutuhan kasih sayang (dari teman) dan kebutuhan ingin dihargai (dari teman menghasilkan puncak kebutuhan aktualisasi diri untuk menampilkan diri sebaik mungkin dengan kemampuan yang dimiliki.

\section{Motivasi kebutuhan Dalam Kematangan Sosial}

Ranah kematangan sosial menurut Fink et al. (2013) antara lain: masuk dalam kelompok bermain, pernyataan diri, kepemimpinan, interaksi sosial, toleransi pada teman sebaya, dan kepekaan sosial. Dari hasil penelitian menunjukkan adanya keterkaitan antara motivasi kebutuhan penggunaan aplikasi Tik-Tok dengan kematangan sosial anak. Deskripsi lebih lengkap sebagai berikut:

a. Masuk dalam kelompok bermain

Anak yang masih berada pada tahap berpikir operasional konkrit mempunyai kemampuan untuk melihat sesuatu dari cara pandang orang lain meskipun cara pandang itu salah. Perilaku yang ditunjukkan dalam pemenuhan kebutuhan fisiologis menggambarkan kemampuan anak dalam menganalisis situasi belum menunjukkan kematangan sosial. Reaksi psikologi anak saat diajak bermain adalah rasa senang. Itu berarti, anak tidak melakukan tahapan berpikir kritis untuk menganalisis situasi sehingga mengambil keputusan bermain Tik-Tok dengan teman dan mengesampingkan kebutuhan fisiologis mengindikasikan tingkat kematangan sosial yang rendah. Hal ini sesuai dengan penelitian Peilouw (2013) menemukan arah hubungan positif semakin tinggi kematangan emosi maka semakin tinggi pula kemampuan pengambilan keputusan.

b. Pernyataan diri

Sudut pandang kematangan sosial anak dapat pula dipengaruhi oleh pemenuhan kebutuhan diri untuk dihargai. Sehingga memunculkan 
perilaku tampak seperti berusaha menjadi lebih baik atau sama dengan teman, menemukan cara untuk tetap nyaman menjalin persahabatan. Memiliki kelompok bermain yang kompak dan saling mendukung juga bagian dari pemenuhan kebutuhan penghargaan. Pernyataan diri ada bagian dari pembuktian tentang diri. Masuk pada ranah aktualisasi diri sebagai dasar motivasi.

\section{c. Kepemimpinan}

Karakteristik kepemimpinan sebagai bentuk dari kebutuhan aktualisasi diri. Hasil penelitian menggambarkan anak dapat menyusun rencana seperti mengatur pertemuan kelompok dan memilih topik diskusi dan pilihan permainan. Bagian ini akan juga masuk dalam ranah aktualisasi diri. Rodiyana \& Puspitasari (2019) menjelaskan pentingnya merasakan atmosfer yang menumbuhkan kepemimpinan bagi siswa SD. Dalam kepemimpinan siswa akan belajar mengelola keadaan psikologis saat berhadapan dengan teman sebaya. Kemampuan siswa dalam menjaga kedisiplinan yang pada akhirnya ditujukan untuk menunjukkan kemampuan diri juga menjadi bagian dari proses kematangan sosial.

\section{d. Interaksi sosial}

Mempererat persahabatan sebagai tujuan bermain Tik-Tok bersama adalah cara anak memenuhi kebutuhan kasih sayang dengan teman. Anak merasa diterima dalam kelompok tentu akan meningkatkan kematangan sosial dengan baik. Kematangan sosial yang didorong oleh motivasi kebutuhan ingin dicintai dalam penelitian ini menghasilkan temuan yang signifikan dengan pemaknaan pada perilaku tampak: anak mampu bersosialisasi dan tidak menemui kesulitan dengan teman sebaya, anak mampu menjaga norma-norma dalam berinteraksi dengan teman sebaya, dan mampu menghargai norma yang dijunjung tinggi dalam menjalin persahabatan. Budikuncoroningsih (2017) berpendapat interaksi dengan teman sebaya merupakan permulaan hubungan persahabatan yang di dalamnya terdapat hubungan timbal balik. Hubungan itu memerlukan usaha dari masing-masing anggota yang mempunyai motivasi kebutuhan ingin diterima, dicintai oleh sahabat. Oleh karena itu masingmasing anak dalam berinteraksi harus menjaga dinamika persahabatan yang baik.

e. Toleransi pada teman sebaya

Saat masuk dalam lingkungan kelompok sebaya dan membentuk kelompok bermain, anak perlu memperhatikan norma yang diterima dan diikuti oleh kelompok. Namun pada kenyataannya norma tersebut dapat tanpa sengaja terlanggar oleh pihak lain. Maka diperlukan toleransi dimana anak belajar menghormati dan menghargai antar teman. Toleransi dalam hubungan anak dengan teman sebaya dapat menjadi tempat anak belajar meningkatkan kematangan sosialnya. Santrock (2013) teman sebaya dalam proses perkembangan sosial anak antara lain sebagai sahabat, stimulasi, sumber dukungan fisik, sumber dukungan ego, fungsi perbandingan sosial dan fungsi kasih sayang.

f. Kepekaan sosial

Dalam motivasi kebutuhan akan penghargaan terutama dari pihak lain, anak belajar mengembangkan perilaku kerja sama dimana setiap anak dapat saling menghormati dan mempercayai. Banyak faktor yang dapat mempengaruhi kepekaan anak. Dukungan orang tua untuk membimbing anak dengan telaten tanpa perlu menyalahkan keadaan zaman dan membandingkan dengan kehidupan lampau. Faktanya kemajuan teknologi tidak serta merta menurunkan nilai kepekaan sosial anak. Hasil penelitian menunjukkan bahwa aplikasi Tik-Tok tidak memberikan (sumbangan) dalam degradasi karakter yang dimiliki siswa sekolah dasar (Adisaputra et al., 2020). Kepekaan anak akan akan tumbuh optimal jika dia merasa diterima dan diperlakukan dengan baik oleh orang-orang terdekat. Langkah kuratif dapat ditempuh jika anak mengalami kesulitan mengasah kepekaan sosial. Wardah, et al. (2020) menemukan upaya guru bimbingan dan konseling dalam mengurangi penggunaan media sosial Tik-Tok yaitu dengan memberikan layanan informasi, layanan klasikal layanan bimbingan kelompok, layanan konseling individual serta kerja sama dengan orang tua siswa.

\section{PENUTUP}

Kesimpulan yang dapat dirangkum sesuai tujuan deskripsi motivasi kebutuhan dalam kematangan sosial antara lain: 1) perilaku yang ditunjukkan dalam pemenuhan kebutuhan fisiologis menggambarkan kemampuan anak dalam menganalisis situasi belum menunjukkan kematangan sosial, 2) kekhawatiran anak terhadap larangan penggunaan gawai menunjukkan belum terpenuhinya kebutuhan rasa aman sehingga membuat tingkat kematangan emosi anak menjadi rendah dan berpengaruh pada kematangan sosial anak, 3) Mempererat persahabatan sebagai tujuan bermain Tik-Tok bersama adalah cara anak memenuhi kebutuhan kasih sayang dengan teman. Anak merasa diterima dalam kelompok tentu akan meningkatkan kematangan sosial dengan baik, 4) kematangan sosial anak dapat pula dipengaruhi oleh pemenuhan kebutuhan diri untuk dihargai. 
Miranti Widi Andriani

Jurnal Bimbingan dan Konseling Ar-Rahman

Volume 7, Nomor 1, Tahun 2021

e-ISSN 2477-6300

Sehingga memunculkan perilaku keamampuan agar diterima kelompok, 5) berperilaku konsisten dan bersungguh-sungguh dalam menunjukkan kemampuan diri, hal ini akan berkaitan dengan keinginan dihargai dan diakui kemampuan dirinya sebagai wujud aktualisasi diri.

Saran yang dapat diberikan untuk penelitian selanjutnya adalah memperluas gambaran pandangan orang di lingkungan sekitar subjek dalam menyikapi penggunaan gawai sosial media.

\section{REFERENSI}

Adisaputra, F., Budyartati, S., \& HS, A. K. (2020). Hubungan penggunaan aplikasi tik tok dengan degradasi karakter siswa SD. Prosiding Konferensi Ilmiah Dasar, 2, 1-10.

Aeni, N. (2011). Perbedaan kecerdasan emosi dan perilaku agresi pada anak yang ditinggal ibu sebagai tkw dengan anak yang tinggal bersama ibunya: studi pada sekolah dasar di kecamatan gabus, kabupaten pati jawa tengah. Widyariset, 14(1), 231-240.

Andriani, M. W. (2018). Keefektifan ChildCentered Play Therapy ( Ccpt ) Untuk Meningkatkan Keterampilan Sosioemosional. 5(2), 245-256.

Anindita, R. P. W. (2020). Makna Penggunaan Aplikasi Tik Tok pada Generasi Z (Studi Fenomenologi terhadap Pengguna Aplikasi Tik Tok). Bachelor Thesis Thesis, Universitas Multimedia Nusantara.

Aprilian, D., Elita, Y., \& Afriyati, V. (2020). Hubungan Antara Penggunaan Aplikasi Tiktok Dengan Perilaku Narsisme Siswa Kelas VIII Di SMP Negeri 8 Kota Bengkulu. Consilia: Jurnal Ilmiah Bimbingan Dan Konseling, 2(3), 220-228. https://doi.org/10.33369/consilia.2.3.220-228

Budikuncoroningsih, S. (2017). Pengaruh Teman Sebaya dan Persepsi Pola Asuh Orang Tua Terhadap Agresivitas Siswa di Sekolah Dasar Gugus Sugarda. JSSH (Jurnal Sains Sosial Dan Humaniora), 1(2), 85. https://doi.org/10.30595/jssh.v1i2.1704

Bujuri, D. A. (2018). Analisis kebutuhan anak usia dasar dan Implikasinya dalam penyelenggaraan pendidikan. JIP:Jurnal Ilmiah PGMI, 4(1), 83-96.

Chusna, P. A., Zakiyah, D., \& Noviani, Z. (2020). Analisis Dampak Fenomena Aplikasi Tik Tok Dan Music Dj Remix Terhadap Penyimpangan Perilaku Sosial Pada Anak Usia Sekolah Dasar. Jurnal Studi Islam AlFikrah, 4(1), 129-147.

Fink, E., Rosnay, M. de, Peterson, C., \& Slaughter, and V. (2013). Validation of the Peer Social Maturity Scale for Assessing Children's Social Skills. Infant and Child Development, 22, 539-552.

Maslow, A.H. (1943). A Theory of Human Motivation A Theory of Human Motivation. Psychological Review, 50, 1-21.

Mendari, A. S. (2010). Aplikasi Teori Hierarki Kebutuhan Maslow Dalam Meningkatkan Motivasi Belajar MahasiswaWidya Warta 82-91. Widya Warta, 01.

Nora, M. O. (2015). Pengaruh Kelekatan dan Harga Diri terhadap Kemampuan Bersosialisasi Anak. Jurnal Pendidikan Anak Usia Dini, 9(2), 379-388.

Novitasari, W., \& Khotimah, N. (2016). Dampak Penggunaan Gadged Terhadap Interaksi Sosial Anak Usia 5-6 Tahun. Jurnal PAUD Teratai, Volume 05(Nomor 03), 182-186.

Peilouw, F. J. (2013). Hubungan Aantara Pengambilan Keputusan Dengan Kematangan Emosi Dan Self-Efficacy Pada Remaja. Character, 1(2), 1-6.

Rodiyana, R., \& Puspitasari, W. D. (2019). Menumbuhkan Kepemimpinan Anak Di Sekolah Dasar. Jurnal Cakrawala Pendas, $5(2)$, 188-194. https://doi.org/10.31949/jcp.v5i2.1442

Santrock, J. W. (2013). Life-Span Development, Thirteenth Edition. McGraw-Hill Companies, Inc.

Susanto, N. H., \& Lestari, C. (2018). Mengurai Problematika Pendidikan Nasional Berbasis Teori Mptivasi Abraham Maslow Dan David Mcclelland. Lembaran Ilmu Kependidikan, 47(1), 30-39.

Trilia. (2018). Hubungan Pemenuhan Kebutuhan Dasar Berdasarkan Hirarki Maslow dengan Motivasi Belajar Siswa SMA. Babbul Ilmi: Jurnal Ilmiah Science Kesehatan, 9(3), 344354.

Wardah, A., Prasetia, M. E., \& Akbar, A. (2020). Upaya Guru Bimbingan Dan Konseling Dalam Mengurangi Penggunaaan Media Sosial Tiktok Pada Siswa Smp Negeri 23 Banjarmasin. Skripsi (e-prints UNISKA), 15.

Dipublikasikan Oleh :

UPT Publikasi dan Pengelolaan Jurnal Universitas Islam Kalimantan Muhammad Arsyad Al-Banjari 